tantalisingly useful literature not readily available in any British library, from such titles as the Indian Fournal of Ophthalmology or Fournal of the Tennessee Medical Association.

Photocopying? Marvellous invention! Never has so much been copied by so many but, I suggest, used by so few. Beware the siege mentality that requires a copy when, previously, reading, digesting, and a few notes would have sufficed

Copyright? Hideous piece of legislation, but, sadly, ours was the lone voice against it as it went through parliament and we are left with the unenviable task of making its impracticalities work. As for licences, Drife is presumably referring to higher education: negotiations between the Copyright Licensing Agency and the NHS broke down long ago and we remain bound by two legal principles-namely, one-person-one-copy for self service copying and one signed declaration form for every copy made on behalf of a reader by library staff. We do not like these restrictions or the extra paperwork they create either, but we have no choice.

In conclusion, I have to say that my district does offer 24 hour access to its library collections, does teach and support the use of CD-ROM and printed indexes, does seek to ensure that readers can make and request copies of material as easily as is legally possible, and does, in short, cater for the wide variety of busy staff who come through the library doors. And I know we are not alone in this.

SLE HF.NSHAW

Salisbury Health Authority,

Salishury General Infirmary,

Salisbury SP2 7SX

1 Drife JO. Doctor in the library. BMf 1992;305:1101. (31 October.)

\section{Access to medical records}

EDrTor,- - The Access to Health Records Act 1990 has allowed patients to have access to their written medical records since 1 November last year. Much debate has centred on the likely effects of this. We carried out a prospective study to assess the impact of the act on patients and staff of the Crichton Roval Hospital, a psychiatric hospital with 398 beds.

During the year there were an estimated 1850 new referrals and 700 admissions, and 8500 outpatients were seen at follow up visits. All medical staff were informed of the study and issued with two questionnaires, one to be given to the patients after they had had access to their notes and another to be completed by themselves and the general practitioner. We aimed to find out why patients requested access and their opinion of the process in terms of ease of access, how well they could understand the notes, the presence of inaccuracies, and usefulness. We also planned to investigate how doctors viewed the effect on patients of reading their notes and whether it entailed spending extra time with them.

On the basis of previous reports, ${ }^{1-4}$ we hypothesised that the act would have an impact in terms of the number of requests for access, the effects on patients, and the time spent explaining what was written. Our hypothesis was inaccurate. Only three patients asked to see their notes. Two others checked that access was possible but did not ask to see the notes. A sixth patient had access to medical reports in a social work file that dated from before 1990. Our numbers are small, but so far we have found no noticeable increase in our workload and no apparent problems for our patients.

MOIRA CONNOLLY RICHARD ATHAWES ALASDAIR MACDONALD

Medical Audit Sub Committee

Crichton Royal Hospital,

Dumfries DG1 4TG
Andersen T, Jorgensen G. Danish experience of statutory right of patients to access hospital records. L.ancet 1988;ii: 1428

Stein EJ, Furedy RI., Simonton MJ, Niejier CH. Patient acces to medical records on a psychiatric inpatient unit. Am Psychiatry 1979;136:327-9

Bernadt M, Gunning L, Quenstedt M. Patients' access to their own psychiatric records. BMf 1991;303:967.

Dillner I. Doctors confused over patients' rights to see medical records. BMF 1992;305:438. (22 August.)

\section{Letting vegetative patients die}

EnrToR,--Bryan Jennett eloquently argues the case for helping patients in a persistent vegetative state to die, arguing that this does no more than bring England into line with some other countries. If tube feeding is treatment, what is being treated? Surely not the brain damage. The food is not being given to correct any abnormal biochemical or pathological process but to provide nutrition to normal tissues. To my mind the tube is simply a tool for daily living, similar to the specially adapted spoons that enable arthritic patients to feed themselves.

The relevance of this is that in identifying tubefeeding as treatment we have found a convenient method of shortening the life of a disabled person. When voluntary euthanasia is accepted as a legal method of medical care starvation is highly unlikely to be an accepted way of assisting the death of the patient. Why then should we choose this method for involuntary euthanasia?

Jennett's argument for helping patients to die because "the recovery of a limited degree of awareness may indeed be worse than nonsentience" is dangerous for two main reasons. Firstly, it implies that we should help someone to die while their clinical state is such that the courts will regard withdrawal of feeding as legally acceptable, so that the patient should not reach a stage of recovery whereby the courts would find it unacceptable to withdraw the feeding. Secondly, the assumption is that no one would want to live severely disabled. As a consultant specialising in chronic disabling disorders I can assure Jennett that, though none of us would wish to be severely disabled, the condition is compatible with a reasonable quality of life within the limits of a person's abilities.

I am not arguing that the decision to assist Tony Bland's death is wrong. We need, however, to be honest about what we are trying to do and find more satisfactory ways of ending such lives than by starvation.

Finally, we must ensure that no decision is made to end the life of a patient in a persistent vegative state before we have offered him or her the opportunity of recovery by admission to a specialist rehabilitation programme. Nor should we make the decision hastily: the BMA's suggestion of one year should be the minimum period.

PV'S Rehabilitation Unit,

Royal Hospital and Home,

London SW $153 \mathrm{SW}$

Jennett B. Letting vegetative patients die. BMf 1992;305: 1305-6. (28 November.)

EDrToR,--My colleagues and I certainly do not believe that all medical treatments must be given to all patients in all situations just because the treatments exist, nor do we believe that food and fluids must be given to dying patients in the last hours of their lives. We disagree profoundly, however, with the recent ruling by the High Court that Tony Bland, who is in a persistent vegetative state, need not be given food and fluids.' We also disagree with Bryan Jennett that this is effectively the last word on the subject of tube feeding such patients.

The first of several key issues is the unargued assertion that tube feeding is a medical treatment. A discussion document of the BMA's medical ethics committee produces no arguments for this but merely makes selective quotations, ' and in the High Court judgment of 19 November Sir Stephen Brown also gave no supportive arguments. Jennett comes closest to some reasons but reveals his own presuppositions when he talks of the "symbolic significance of feeding." Surely food and fluids are basic to life itsclf, not symbolically significant?

Has Jennett also decided that Tony Bland is already dead? Sir Stephen Brown said, "To his parents and family he is 'dead.' His spirit has left him and all that remains is the shell of his body.' This, however, is outside present medical (and hence legal) concepts of death, which are the cessation of cardiorespiratory function and brain stem death. This is a new philosophical concep based on the absence of sentience and rationality, and society should not be bounced by this tragic case into redefining death without a great deal more thought as many more categories of patients would thereby become involved. If the concept of Tony Bland being dead already is accepted in law we will have moved the goalposts medically, legally, ethically, philosophically, and theologically.

What is the intention of the planned omission? Rather than continuing to deceive ourselves with euphemisms about cessation of futile medical treatment we must honestly conclude that the intention is for Tony Bland to die. This is intentional killing by omission, which, as the official solicitor in the case argued, is murder.

Tony Bland is not terminally ill but is a living person who deserves food and fluids as part of basic nursing care. Should he develop an overwhelming pneumonia it would be an entirely legitimate medical decision if antibiotics were not given. $\mathrm{He}$ might then die. If so he would die from pneumonia and the persistent vegetative state; if the proposed plan is followed he will inevitably die of intentional starvation and the persistent vegetative state.

I urge the profession, society, and the law to think again.

Healthcare Opposed to Euthanasia,

ANDREW FERGUSSON

London SE11 5TN

\section{Dyer C. High Court rules doctors can stop feeding Tony Bland 2. (28 November.)} 1305-6. (28 November.)

BMA Medical Ethics Committee. Discussion paper on trcatment of patients in persistent vegetative state. London: BMA, 1992.

\section{Information for patients}

Enrtor,-Tim Albert and Stephanie Chadwick's article about practice leaflets' reminded me of my trips round North West Thames region when I arived in my present job. At each hospital I asked to see the standard patient information leaflet to get an idea of the message the hospital chose to delive to its patients. One famous teaching hospital still identified the Great Western Railway on its map, while the first piece of information delivered to inpatients at a hospital in north London was the fact that it had been the model for the workhouse in Oliver Twist.

Tony Smith advises doctors to seek help in writing material for patients. ${ }^{2}$ NHS public relation departments employ professional writers, mostly trained in journalism. Many-and certainly mine - are delighted to help general practitioners as well as hospital departments with the whole package from copywriting to design and production.

North West Thames Press and
Public Relations,

JONATHAN STREET

Public Relations,

London W2 3QR

Albert T, Chadwick $S$. How readable are practice leaflets? $B M$ 1992;305:1266-8. (21 November)

2 Smith T. Information for patients. BMF 1992;305:1242. (2 November.) 